\title{
Relationship between Personality Trait and Spiritual Intelligence among Trainee Teachers at the Institute of Teacher Education Malaysia
}

\author{
Zuraini Idris, Ku Suhaila Ku Johari, Abu Yazid Abu Bakar
}

To Link this Article: http://dx.doi.org/10.6007/IJARBSS/v11-i12/11952

DOI:10.6007/IJARBSS/v11-i12/11952

Received: 13 October 2021, Revised: 19 November 2021, Accepted: 30 November 2021

Published Online: 26 December 2021

In-Text Citation: (Idris et al., 2021)

To Cite this Article: Idris, Z., Johari, K. S. K., \& Bakar, A. Y. A. (2021). Relationship between Personality Trait and Spiritual Intelligence among Trainee Teachers at the Institute of Teacher Education Malaysia. International Journal of Academic Research in Business and Social Sciences, 11(12), 2333-2346.

Copyright: (c) 2021 The Author(s)

Published by Human Resource Management Academic Research Society (www.hrmars.com)

This article is published under the Creative Commons Attribution (CC BY 4.0) license. Anyone may reproduce, distribute, translate and create derivative works of this article (for both commercial and non0-commercial purposes), subject to full attribution to the original publication and authors. The full terms of this license may be seen at: http://creativecommons.org/licences/by/4.0/legalcode

Vol. 11, No. 12, 2021, Pg. 2333- 2346

Full Terms \& Conditions of access and use can be found at http://hrmars.com/index.php/pages/detail/publication-ethics 


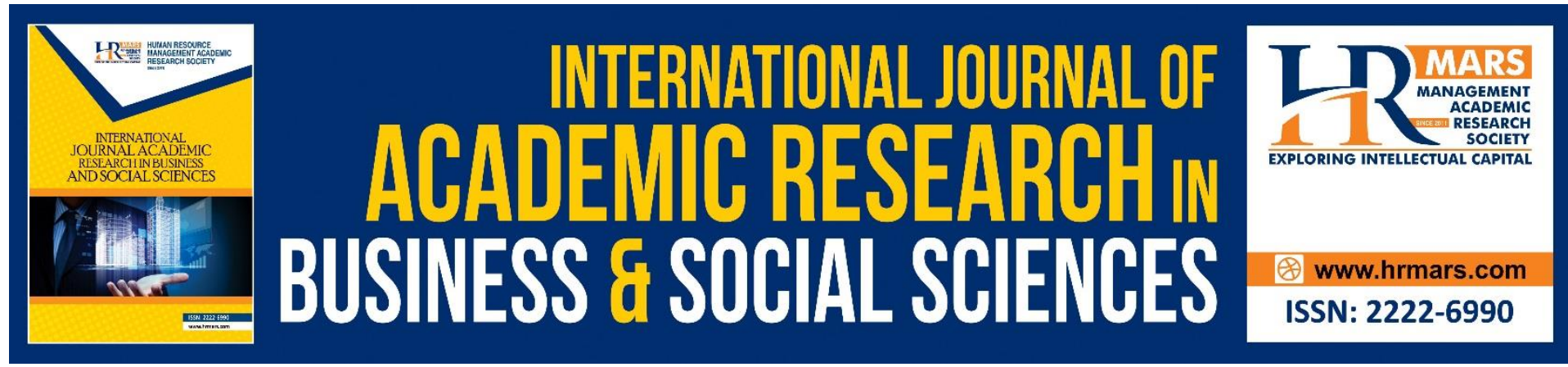

\title{
Relationship between Personality Trait and Spiritual Intelligence among Trainee Teachers at the Institute of Teacher Education Malaysia
}

\author{
Zuraini Idris, Ku Suhaila Ku Johari, Abu Yazid Abu Bakar \\ Faculty of Education, National University of Malaysia (UKM), Bangi, Malaysia \\ Email: suhaila@ukm.edu.my
}

\begin{abstract}
The purpose of this study was to examine the relationship of personality traits (Openness, Awareness, Extraversion, Acceptance and Emotional Stability) with spiritual intelligence among semester 6 trainee teachers in IPGK central zone in Malaysia. A total of 207 respondents were involved in this study ( $75=$ male; $132=$ female). The research tools used were measures of spiritual intelligence from the instruments of Rayburn \& Richmond (1999); Goleman-Noriah (2005); Lee (2010); (Chin, 2015) and the International Personality Item Pool (IPIP) (Goldberg, 1992). The findings of the study showed that there was a positive relationship between Extraversion personality traits $(r=0.152, p<0.05)$ and Openness $(r=$ $.140, p<0.05)$ with spiritual intelligence. Whereas for the personality trait dimensions of acceptance $(r=-0.043, p<0.05)$, awareness $(r=0.052, p<0.05)$ and emotional stability $(r=-$ $0.006, p<0.05)$ showed no relationship with spiritual intelligence. This finding explains that with the possession of increasingly positive and quality personality traits making prospective teachers to also practice the personality behavior of a teacher is also at a high level. The implication is that trainee teachers who have personalities for the following four dimensions can consistently play a role in shouldering their responsibilities as teachers to meet the needs of the challenges of change that occur in today's educational organizations.
\end{abstract}

Keywords: Personality Traits, Spiritual Quotient, Big Five

\section{Introduction}

In bucking the tide of globalization in the 21st century, each individual has the potential and advantages that can be polished and expanded. It affects the development and growth of physical, cognitive, psychomotor and emotional. This requirement is seen in line with the National Education Philosophy (FPN) where the field of education focuses on holistic development in terms of intellectual, spiritual, emotional and physical. Therefore, being selected to attend teaching training at the Institute of Teacher Education has greater challenges in realizing the needs of FPN which is the basis of career excellence in the profession of jealousy (Kahirol et al., 2008). The process of strengthening human capital for educators in practicing consistent personality traits is the most important issue in the development of an excellent education system. Therefore, managing complex changes in education affects in determining the achievement of work that can be scrutinized through 
the ownership of personality traits and behavioral practices. These individual differences can be seen based on the characteristics and behaviors that a person has described as personality (Maccoby, 2009). A career in teaching is a profession that has its own role in shaping the next generation (Khairul, 2013). The formation began from the formation of personality, the vision of the Institute of Teacher Education Malaysia (IPGM) as the leader in teacher education excellence is to meet the needs of Shift 4 in the new transformation of education. Therefore, The mission of IPGM is to produce competent and educator-souled teachers through dynamic teacher development programs towards world-class school education. A teacher with an educator's mind can be born if a teacher is ready to equip themselves with skills, knowledge and is inclined to possess the personality of a teacher (Zulelawati and Yusni, 2015). The tendency of a person to have a personality that aligns with a career background can help an individual achieve work stability (Sidek, 2008).

\section{Background of The Study}

Personality issues are the main pillars of the selection of careers that are suitable for each individual. Teachers should not only be prepared with knowledge and skills but teachers also need to be prepared in terms of personality as it is a benchmark for excellence in the profession. Teachers who have friendly, friendly, caring personalities and so on can attract students to learn (Nor, 2005). Excellent teachers are often associated with personality or personal characteristics. According to a Grieve study (2010) an excellent teacher with aspects of self-quality and interpersonal skills. This review was agreed by Hay McBer (2000) An excellent teacher is a teacher capable of displaying empathy, encouraging, giving students a sense of safety will be loved by his students.

\section{Study Issues}

Every year educational institutions in Malaysia undergo changes in the pattern of administrative management or in the implementation of the education system (Yahaya, 2009). This situation shows the importance of changing the educational aspect to society is not to be disputed as it is the heart of the development and civilization of a country. Such changes should guarantee better quality improvements to job creation. In fact, changes in the implementation of the education system are aimed at improving school achievement, often associated with the quality of personality traits of teachers found in the school organization. This is the main challenge in education, namely to produce prospective teachers who are ready to equip themselves with knowledge and skills and have a personality that suits the characteristics of a teacher (Zuraini et al., 2019). Therefore, the relationship between the more dominant personality traits in prospective teachers and their association with spiritual intelligence is specifically reviewed through this study.

Therefore, past researchers conducted studies on personality among teachers. The personality factor of the teacher is important, of which the teacher is the leader of the sponsor. As McCormack \& David (2002) studies, teacher personality factors have been found to contribute to the effectiveness of leadership style among leaders and impact work performance achievement in the organization. To influence the student, the teacher needs to behave positively and have qualities as a teacher based on the personality that is already in him. Thus, personality describes the traits that an individual has such as the way a person thinks, responds, is emotional, conceptual and others so that personality can allow the leader to be distinguished from other individual followers (Mahmood, 1990). The 
importance of this aspect of teacher personality and spiritual intelligence raises questions about the extent to which this issue is explored in local education studies?

\section{Definition of Personality Concept}

The definition of personality was first popularized in 1961 by Allport. But according to Meningger (1930), the term has been used since the early 20th century. The use of the term personality today has soared across a variety of disciplines. The use of the term personality across disciplines leads to the emergence of diverse definitions due to the influence of different backgrounds of knowledge disciplines and dimensions.

For Meningger (1930), defining personality as nothing in elaborating on a person who focuses more on the biological and physiological aspects of the individual. Unlike Allport (1961), personality refers to something dynamic consisting of a network of psycho-physical systems to determine unique and distinctive adaptations to the environment. Meanwhile, personality also translates as development for the entire psychological system by conducting research in aggregate rather than focusing only on a few parts of character only (Abdul Razak \& Ainin, 2000).

With regard to personality as a psychological system, the psychological detail includes individual traits such as way of thinking, acting, emotional, conceptual and others that differ from other individuals (Mahmood, 1992). In this regard, the psychologist Sigmund Freud refined personality as a result of the integration between the structures of the id, ego and human superego. (Huffman, 2007). The definition is different from Carl Jung who considers it an ego integration, a personal unconscious realm, a collective unconscious, complex and some other structure (Huffman, 2007). Costa and McCrae (1992) detail the definition of personality as intellectually and physically stable characteristics and habits including thought, emotional and behavioral patterns in various situations. The reality of such definitions is completely different from the views of Islamic scholars who refer personality to spirituality, psychicism, morals and manners (Al-Ghazali, 1966). However, only four dimensions are discussed in the writing of this article namely openness, social nature (extraversion), reaching consensus and awareness (conscientiousness). This is because most past studies have shown personality traits, namely for the dimensions of neuroticism (tending to anxiety, depression, and anxiety are less and insignificant among leaders (Barrick et al., 1998).

\section{Concept of Spiritual Intelligence}

The concept of intelligence emerged within the framework of ancient philosophy and has remained a consistent topic of interest for philosophers and writers throughout the ages to this day. Nevertheless, in recent decades, witnessed an extension of this framework of reference to encompass the study of contemporary research in the biological and physiological sciences, particularly anorexia and bulimia nervosa physiology, heredity, and finally the field of humanity. The term and concept of spiritual intelligence emerged as a result of the union of intelligence with spiritual intelligence (Mahasneh et al., 2015).

When accepting equality and solidarity between religion and spirituality or spirituality, there is also consensus on their differences and differences, religions that focus on the sacred while spiritual refers to the elements of experience of meaning, superiority, and 
excellence (Worthington, 2001). Researchers consider spiritual intelligence to be the most significant type of intelligence because its ability influences change in people, societies, and cultures. Thus, improving spiritual intelligence helps individuals toward to apply positive views and in achieving inner peace. This attitude modification increases self-motivation and control and helps reduce the level of high stress commonly caused by the pace of modern life (Nurul et al., 2012). Religion and moral values will be the controller of human life and in the construction of personality which if firmly embedded then the stronger its influence in the control of behavior and attitude formation. The ability to face and solve questions of meaning and value, i.i. intelligence to place behavior and life in the context of a broader and richer meaning, intelligence to judge that one's actions or way of life are more meaningful is called spiritual intelligence (Zohar \& Marshal, 2007).

Individuals who achieve spiritual awareness: 1) Coordinating world harmony as a whole beyond self-sedation;2) being aware of spiritual conditions is higher than thinking and meditating; 3) be aware of the spiritual dimensions covering activities, events, and daily relationships; 4) build awareness, taking into account daily problems in the context of life parameters; and 5) Always desire to improve or improve yourself, by carrying out practice forgiving, appreciation, gratitude, and practice low self-esteem and empathy (Mayer, 2000).

Wilber mentions that spiritual intelligence develops and increases in the individual covering three stages: 1) the beginning of the stage, in which attention is focused on oneself through moving towards God by pleading with Him, by praying and thanking him for His mercy, the gift of peace and peace, salvation, and security in the face of personal hardship; 2) conventional level, which refers to harmony and solidarity with religion, the development of self-interest for the benefit of others; and 3) post-conventional levels, or the transition from a moderate level of commitment to a level of spiritual and religious consciousness encompasses the broader aspects of self-awareness by understanding various ways and methods so as to gain awareness and conformity with reality (Emmons, 2000)

\section{Past Reviews}

Relationship Between Personality Traits Of Consciousness, Acceptance, Emotional Stability, Extraversion and Openness with Spiritual Intelligence

A research study was conducted on $\mathbf{2 7 0}$ male students at Shahid Chamran University in Ahvaz, studying the relationship between personality traits and spiritual intelligence. The results showed statistically significant correlation between extraversion, agreeableness and conscientiousness with critical existential thinking, personal meaning, transcendent awareness, and conscious-state spiritual intelligence, but showed no association between neurosis and trait personality openness and subscaleism. Intelligence of spiritual intelligence (spiritual intelligence subscales) (Beshlidah et al., 2011).

From references to past studies, the researchers found that personality research conducted by psychologists and other areas of social sciences were based on two different instruments which are using Big Five Personality Inventory dan NEO Personality Inventory-Revised (NEOPIR; Costa \& McCrae,1992) However, other study tools also have the same opportunity to be used in studying personalities such as 16PF, MBTI and others. Review by Judge et al. (2000), concluding the use of different personality instruments has been widely used in 
various sectors of employment such as aviation Grant et al (2007), politics Schoen \& Schumann (2007), entrepreneurship Zhao \& Seibert (2006), and others.

The findings from past studies also explain that only certain personalities can relate to spiritual intelligence. A study to identify the level of spiritual intelligence and its association with personality among a group of undergraduate students in Jordan was carried out. A sample aimed at 716 male and female students was selected from different faculties at Hashemite University in Jordan. Spiritual intelligence questionnaires and personality questionnaires were distributed to sample members in the 2013-2014 academic year. The results showed a moderate level of spiritual intelligence among students, and showed a statistically positive and significant relationship between the four dimensions of spiritual intelligence (critical existential thinking, the production of personal meaning, transcendental consciousness, and the development of a conscious state) and This indicates a reality interconnected between three dimensions of personality (neurotism, extraversion, openness to experience, willingness, and thoroughness). Yet the results, insignificant correlation between two spiritual intelligences, the production of personal meaning and the dimensions of transcendental consciousness with the personality of neuroticism (Mahasneh et al., 2015).

The study of 121 different respondents, a physical education manager, examined the relationship between spiritual intelligence and personality traits. The results showed a positive and significant correlation between spiritual intelligence (critical thinking, creating personal meaning, transcendental consciousness, and developing consciousness) and excessive personality traits, pleasure, awareness, and openness to experience. The results also showed a negative and significant relationship between the subscale of spiritual intelligence and neurotic personality traits. (Farsani et al., 2013). While the study of 120 students at the National Open University in Jammu and Indira included a link between personality traits, spiritual intelligence, and well-being. Results showed there was a positive relationship between self-meaning generation and the appropriateness of agreeableness and neurotism, and a significant link between transcendental consciousness and the trait of openness (Sood et al., 2012). For example, a study of 205 students at Tehran University to study the relationship between personality traits and spiritual intelligence. The results showed a positive relationship between the three personalities characteristics of consciousness, conscientiousness, and extrovert with spiritual intelligence, but the negative relationship between neurotism and spiritual intelligence, while also the results of the study showed no link between openness of openness and spiritual intelligence (Amrai et al., 2011).

\section{The Importance of Personality Traits to The Development of a Teacher's Personality}

Awareness Personality Trait (conscientiousness)

Generally, the Five-Factor Personality Model for the dimension of conscientiousness awareness explains that this element is always cautious, conscientious, overly cautious, and reliable. This type of personality has a vigilance attitude, a responsible person, managed, disciplined, efficient, hardworking, systematic, always in a well-planned state and prioritizes achievements (Barrick \& Mount, 1991). This personality that is concerned with the achievement of these results is very helpful for teachers in the process of complex and complicating changes. During the process, focused research needs to be emphasized so that 
it can help provide more specific skills if there is new responsibility, new skills and this can improve the working capacity as well as it can facilitate the process of change of work takes place in a harmonious environment.

Moreover, individuals of this element are also associated with abilities in the aspects of neat management and administration of work. They always plan and manage time in the context of a work environment that requires agile adaptation to all forms of transition processes taking place. This situation can be seen to help during periods of career change as such individuals tend to analyze and practice appropriate behaviors that can be used in the face of any new form of work (Costa \& McCrae, 1992). Therefore, such attribution is stated to be very important and necessary for each teacher in order to create good work performance. This individual trait that easily explores in detail all the actions that will be taken can help the individual to weather the crisis of change and through this process of adaptability more easily.

Extraversion Personality Trait

Meanwhile, (Colman, 2009; Goldberg, 1993; Costa et al., 1992), extraversion was defined as a trait that belonged to a person who was social and assertive. Extraversion refers to the simple and comfortable nature of connecting with its environment. This trait refers to the nature of a person who likes to socialize and has high social skills, is quick to be friendly and talkative and a crowded atmosphere. This trait refers to individuals who have interpersonal relationship characteristics, need external stimulation, elements of assertiveness, love to talk and socialize, are kind, love the outside world, have high emotional sensitivity and constantly aroused thinking patterns (Costa \& McCrae 1985). Extraversion is an act, situation, or habit that mostly seeks satisfaction from outside of oneself, defined as a trait characterized by a deep interest in others and external events, very confident of exploring something that has never been known (Ewan, 1998).

These individual advantages of extraversion qualify them as leaders who are capable of bringing positive change to the improvement of commendable performance achievements of the organizations it leads. On the other hand, individuals who scored low in elements of awareness (extraversion) were found to be incompetent and socially avid, quiet, timid and disrespectful from the public, giving them difficulty dealing with others (Costa \& McCrae,1992).

\section{Acceptance Personality Trait}

In summary, individuals described as 'agreeableness' are to have such attributes as tolerant, helpful without expecting a reply (altruism), easy cooperation, generous, jolly, courteous and forgiving features (Barrick \& Mount, 1991). According to (Colman, 2009; Goldberg, 1993; Costa et al., 1992), Acceptance is defined as generous. kind, friendly and reliable. A person who is high in the level of acceptance is referring to an attitude that cares about cooperation and a harmonious atmosphere.

According to Barrick \& Mount (1991) reports that individuals who are inclined to such traits are expected to exhibit good work performance in various employment contexts, especially those involving relationship skills. Meanwhile, Costa and McCrae (1992) explain individuals with high levels of agreeableness are said to have a simple working nature, have a gentle personality and courtesy. 
Openness Personality Trait

Meanwhile, for the openness element this individual's personality is a person with a high curiosity, likes to explore things with more detailed, wise, open thinking patterns, openness and high imagination. This individual is open to accepting new ideas. In fact, according to a study conducted by Bing and Lounsbury (2000) This element is exhibited as a medium that is very influential on work performance for a unique organization when focusing on the process of learning new skills and focusing on the emergence of new and creative ideas during the process of doing something work done. McCrae and Costa (1991), These individuals love exploring new and more focused experiences. The individual thinking of this open personality type displays a creative and flexible thinking pattern (Digman ,1990). Therefore, it is easily connected to self-sedation to the changes taking place and demands changes in new work patterns, decision-solving, problem solving and changes in the organization (LePine et al., 2000).

\section{Study Methodology \\ Study Design}

The design of the study is a descriptive survey study using a quantitative approach using questionnaires. Researchers made this selection after considering the objectives of the research studies that were outlined in the study. This study is a collaborative study as according to Tuckman (1934), a collaborative study studying the variables that have occurred and existing ones exist in social units before starting to do the study. It will determine the relationship and relationship between personality variables and spiritual intelligence. The relevance between these variables is used to make predictions to the results of the study. Researchers formulated the data of such studies suitably for analysis using statistical procedures and questionnaires as instruments of study. Finding data collection techniques using questionnaires is appropriate and predictively used because researchers presented data in the form of numbers (Dul and Hak, 2008).

\section{Study Instruments}

The data was collected using questionnaires namely Spiritual Intelligence from (Rayburn \& Richmond instruments, 1999, cite in Chin (2015) which contained 39 items using a 5-point Likert scale to measure spiritual intelligence and the International Personality Item Pool (IPIP) questionnaire (Goldberg, 1992) which had 25 items using a 5-point Likert scale to measure personality.

\section{Subject and Place of Study}

The subjects of the study involved in this study were 207, respondents ( $132=$ males; $174=$ females) consisted of prospective PISMP teachers Recruited June 2018 who were in their 6 th semester of study at the IPGK in the central zone. Central zone IPG refers to the IPG listed in the central region, consisting of IPG Malay Bahasa Campus, IPG International Language Campus, IPG Special Knowledge Campus, and IPG Islamic Education Campus (IPGM, No. 13/2010). 


\section{Results of The Study and Discussion}

\section{Relationship Between Personality Traits Acceptance, Mindfulness, Extrovert, Emotional} Stability and Openness to Spiritual Intelligence.

The results of the study using Pearson correlation analysis showed that there was a positive relationship of extraversion personality traits $(r=0.152$ : $p<0.05)$, openness $(r=0.140 ; p<0.05)$ with spiritual intelligence. The findings show that extraversion personalities correlate positively with spiritual intelligence compared to other personality traits. This explains the higher the level of sociable personality eccentrical, positive emotions, ambitious, friendly, more friendly the more influence increases the level of spiritual intelligence possessed by a trainee teacher. The findings are shown as per Table 1 below.

Table 1 Analysis of the correlation of relationships between traits of prudent personality, consensus, openness of mind and extraversion with transformational leadership behavior

\begin{tabular}{ll}
\hline Personality dimension & Spiritual Intelligence \\
\hline extraversion & $0.152(* *)$ \\
Openness & $0.140\left(^{* *}\right)$ \\
\hline $\mathrm{N}=207$ & $*$ significant at the level $p<0.05$
\end{tabular}

While for acceptance traits $(r=0.043, p<0.05)$, consciousness $(r=0.052, p<0.05)$ and emotional stability $(r=0.006, p<0.05)$ are found to have no connection to spiritual intelligence. A summary of the results is shown in Table 4 below.

Table 2 Analysis of the correlation between the traits of prudent personality of openness of mind and extraversion with spiritual intelligence.

\begin{tabular}{lll}
\hline \multicolumn{1}{c}{ Personality dimension } & Spiritual Intelligence \\
\hline Acceptance & 0.043 & \\
Awareness & 0.052 & \\
Emotional Stability & 0.006 & \\
\hline $\mathrm{N}=306$ & & ${ }^{*}$ significant at the level \\
$p<0.05$ & &
\end{tabular}

\section{Discussion}

In general, the results of this study show that there is a relationship between personality and spiritual intelligence. As the study by (Saroglou, 2010), the most obvious relationship is between conscientiousness and spiritual intelligence. The correlation between these two variables is statistically significant. In other words, when a person's conscientiousness score is higher, their spiritual intelligence score will be higher. This explains easily how conscientiousness is associated with spiritual intelligence. According to the positive relationship between conscientiousness, spirituality and religious tendencies (Saroglou, 2010), one can understand that the core of the center of thoroughness is a combination of being bound by values and avoiding emotional over bursts and malfunctions. After conscientiousness, acceptance is the second personality trait that has a positive and significant relationship with spiritual intelligence. Generally speaking, conscientiousness and 
acceptance are two personality traits whose positive association with religious beliefs and attitudes has been proven in many studies (Saroglou, 2010).

Spiritual intelligence has a relationship with personality. The research show a moderate level of spiritual intelligence in the advent of students in Jordan. These results can be explained based on the need for the concept of spiritual intelligence and consequently the lack of recognition by the university as a bona fide field of study. In focusing on academics, researchers suggest to pay attention also in improving programs and training in the effectiveness of aspects of spiritual intelligence can also help to uplift the dignity of students and further enrich the university (Mahasneh et al., 2015).

The findings show that extraversion personality correlates positively with spiritual intelligence. Openness personality obtained consistent results through the results of a study by Cavazotte et al. (2012) that reported that openness had a strong correlation. These results are consistent with the results of studies by (Judge et al., 2000; Jones et al.,2005) the study noted that individuals with openness personalities are usually creative, imaginative, highly confident, easier to transform themselves, others and organizations in driving their inspired vision. The findings were agreed through the findings of Judge et al. (2000) which stated that individuals with high openness typically have high scores for intellectual stimulating dimensions.

A study by Sternberg (1997) On the positive relationship between spiritual intelligence and extraversion, these results can be described based on the logical relationship between the concept of spiritual intelligence and the characteristics of extraversion, cheerful, friendly, and friendly people in their social relationships; in addition, they are characterized by a healthy spirit, enjoy all kinds of physical activity, and feel positive emotions such as happiness, love, joy, and pleasure. It is seen the creation of a personal meaning as the ability to build a character and identify the purpose of all physical and mental experiences, including the ability to establish goals and interests for life, as well as meditation on existence. It is known that the character is sometimes described as a spiritual element, which indicates that spiritual intelligence implies considerations about the importance of events and personal circumstances in order to generate purpose and meaning for all life experiences.

\section{Conclusion}

The findings of the study of extraversion personality traits and openness have a significant relationship with spiritual intelligence. Meanwhile, the traits of acceptance personality, awareness and emotional stability show have no connection with spiritual ingenuity. As a result, educators are unable to establish relationships on the importance of developing organizations holistically in order to inculcate positive personality traits.

In this situation, identifying personality traits for a teacher explains the positive qualities of individuals who contribute to the strengthening in educational institutions in the new millennium in line with current challenges that are seen as critical phenomena that need to add value. In this regard, teachers with personality for the following four dimensions can positively play a role in meeting the challenges of change. In fact, it is now the teacher's responsibility to practice the personality element consistently in their respective environments at all levels. 
In this regard, the importance of spiritually intelligent personality is important in the teacher's career is a reasonableness that teachers need to have in order to produce quality work. Most of the successful teachers today are among those with their own character. This factor is closely related to the personality that belongs to a person who is able to form positive behaviors in each of the things that are performed. He stressed that teachers should have personalities who can reflect their authority in managing the human capital of the country with positive skills in all matters in education and administration. Positive skills are not only external such as the way of dressing neatly and cleanly but also internal attributes such as mutual empathy, affection, respect and having the highest patience in managing the needs of oneself and its students to reach agreements and cooperation from all parties.

Naturally, there is no denying that to be an authoritative and well-respected teacher depends not only on academic qualifications, knowledge or experience alone, but also to have a consistent personality that can be upstanding and convincing in influencing the people around him.

Therefore, each educator requires a positive personality trait that is consistently polished throughout carrying out trust in their work. This is because they will be role models in interacting with students, parents, staff, the administrators, also in the community. This directly plays a role in shaping human capital with positive values in educational institutions. Therefore, having a good personality qualities of spiritual intelligence it will lead to a productive and world-class educational service practice in realizing the vision of national education. 


\section{References}

Allport, G. W. (1961). Pattern and growth in personality. New York: Holt, Rinehart \& Winston.

Amrai, K., Farahani, A., Ebrahimi, M., \& Bagherian, V. (2011). Relationship between personality traits and spiritual intelligence among university students. Procedia Social Behavioral Science, 15, 609-612

Asghari, S. A., Kazemi, A., \& Mousavi, S. V. (2019). The role of personality traits in predicting the spiritual intelligence of senior high school students in Bostanabad. Journal Religion Health, 4(5), 67-76.

Barrick, M. R., \& Mount. M. K. (1991). The big five personality dimensions and job performances: a meta-analysis. Personnel Psychology, 44, 1-26.

Barrick, M. R., \& Mount, M. K. (1993). Autonomy as a moderator of the relationship between the big five personality dimensions and job performance. Journal of Applied Psychology, 78(1), 111-118.

Barrick, M. R., Mount, M. K., \& Judge, T. A. (2001). Personality and job performance at the beginning of the new millennium: what do we know and where do we go next? International Journal of Selection and Assessment, 9, 9-30.

Barrick, M. R., Stewart, G. L., Piotrowski, M. (2002). Personality and Job Performance: Test of the Mediating Effects of Motivation Among Sales Representatives. Journal of Applied Psychology, 87(1), 43-51.

Bass, B., \& Avolio, B. (2000). MLQ: Multifactor Leadership Questionnaire. $2^{\text {nd }}$ edition. Technical Report. Redwood City, CA :Mind Garden.

Beshlideh, K., Charkhabi, M., Kalkhoran, M., \& Marashi, S. A. (2011). Relationship between personality traits and spiritual intelligence in male students of Shahid Chamran University at Ahvaz. International Journal Psychology, 5(1),21-34.

Bing, M. N., \& Lounsbury, J. W. (2000). Openness and Job Performance in U. S.-based Japanese Manufacturing Companies. Journal of Business and Psychology, 14, 515-522. Form S and Form R. Florida: Psychological Assessment Resources.

Bono, J. E., \& Judge, T. A. (2004). Personality and Transformational and Transactional Leadership: A

Meta Analysis. Journal of Applied Psychology, 89(5), 901-911.

Campbell, J. P., McCloy, R., Oppler, S., \& Sager, C. (1993). A Theory of Performance. In N.Schmint and W. Borman. Personnel Selection In Organization (pp. 35- 70). San Francisco: Joossey- Bass.

Costa, P. T., \& McCrae, R. R. (1989). NEO PI-R Professional Manual. Odessa.F1: Psychological Assessment Resources. Inc.

Coetzee, C., \& Schaap, P. (2005). The relationship between leadership behavior, outcomes of leadership and emotional intelligence. Journal of Industrial Psychology, 31(3), 31-38.

Digman, J. M. (1990). Personality Structure: Emergence of the Five-Factor Model. Annual Review of Psychology, 41, 417-440.

Don, Y. (2009). Korelasi dan Pengaruh Kompetensi Kecerdasan Emosi Terhadap Kepimpinan Sekolah: Perbandingan Antara Sekolah Berkesan dan Sekolah Kurang Berkesan. Tesis PhD. Universiti Malaya

Emmons, R. (2000). Is spirituality an intelligence? Motivation, cognition and the psychology of the ultimate concern. International Journal Psychology Religion, 10(1), 3-26.

Emmons, R. (2000). Spirituality and intelligence: Problems and prospects. International Journal Psychology Religion, 10(1),57-64. 
Ewen, R. B. (1998). Personality: A Topical Approach: Theories, Research, Major Controversies, and Emerging Findings. Mahwah, NJ: Lawrence Erlbaum.

Farsani, M. E., Arofzad, S., Hosaini, T. A. (2013). The study of the relationship spiritual intelligence with personality traits among physical education managers in Isfahan province. Applied Science Research, 4(4),140-144.

Goldberg, L. R. (1992). The Development of Markers for the Big Five Factor Structure. Psychological Assessment, 4, 26-42.

Goldberg, L. R. (1998). International Personality Item Pool: a scientific collaboratory for the development of advanced measures of personality and other individual differences. http//ipip.ori.org/ipip/ipip.html [24 Jun 2006].

Grieve, A. M. (2010). Exploring the characteristics of 'teachers for excellence': teachers' own perceptions. European Journal of Teacher Education. 33(3): 265- 277

Mahasneh, A. M., Shammout, N. A., Alkhazaleh, Z. M., Al-Alwan, A. F., \& Jawhara, D. A-E. (2015). The relationship between spiritual intelligence and personality traits among Jordanian. Psychology Research and Behavior Management Journal, 8, 89-97.

McBer, H. (2000). Research Into Teacher Effectiveness. London: Department for Education and Employment.

Huffman, K. (2007). Psychology in Action. 8th Ed. USA: John and Wiley.

Ibrahim, A. R., \& Sulaiman, A. (2000). Gelagat Organisasi. ed. 8. Selangor: Pearson Education Malaysia Sdn. Bhd.

Idris, Z., Johari, K. S. K., \& Bakar, A. Y. A. (2018). Meta-Synthesis Study: Positive Effects on Positive Personality of Teachers in Teaching Profession. International Journal of Academic Research in Business and Social Sciences, 8(1), 737-746.

John, O. P., \& Srivastava, S. (1999). The Big Five Trait Taxonomy: History, Measurement and Theoretical Perspectives. In L. A. Pervin \& O. P. John (Eds.), Handbook of Personality: Theory and Research (pp. 102-138). New York: Guilford.

Judge, T., \& Bono, J. E. (2000). Relationship of core self-evaluation with job satisfaction and job performances: a meta-analysis. Journal of Applied Psychology, 86(1), 80-92.

Mayer, J. (2000). Spiritual intelligence or spiritual consciousness? International Journal Psychology. Religion, 10(1), 47-56.

Mohamed, M. N. (1990). Pengantar Psikologi: Satu Pengenalan Asas Kepada Jiwa dan Tingkah laku Manusia. Kuala Lumpur: DBP.

Nawi, N. H. M., Redzuan, M., \& Hamsan. H. (2012). Inter relationship between emotional intelligence and personality trait of educator leaders. International Journal of Academic Research in Business and Social Sciences, Vol.2, No.5, pp.223- 237.

Saroglou, V. (2002). Religion and the five factors of personality: a meta analytic review. Personality and Individual Differences, 32, 15-25.

Saroglou, S. (2010). Religiousness as a cultural adaptation of basic traits: A five-factor model perspective. Personality and Social Psychology Review, 14, 108-125.

Sood, S., Bakhshi, A., \& Gupta, R. (2012). Relationship personality traits, spiritual intelligence and well-being in university students. Journal of Educational Practice, 3(10),55-59.

Sternberg, R. J. (1997). Successful Intelligence: How Practical and Creative Intelligence Determine Success in Life. New York: Plume.

Vaughan F. (2002). What is spiritual intelligence? Journal Humanist Psychology.42(2):16-33.

Worthington E. (2001). Religion and spirituality. Psychotherapy. 38(4): 473-478.

Yusoff, M. S. M., \& Mohamed, N. S. (2004). Peningkatan prestasi di tempat kerja melalui aplikasi kecerdasan emosi. Jurnal Pengurusan Awam, 3(1), 1-20. 
INTERNATIONAL JOURNAL OF ACADEMIC RESEARCH IN BUSINESS AND SOCIAL SCIENCES

Vol. 11, No. 12, 2021, E-ISSN: 2222-6990 @ 2021 HRMARS

Zohar, D., \& Marshall, I. (2000). SQ: Connecting with Our Spiritual Intelligence. New York:Loomsbury. 